\title{
Perkecambahan Biji Dan Pertumbuhan Kecambah Varietas Sorgum (Sorghum bicolor L.) Pada Cekaman Krom Heksavalen
}

\author{
Sri Kasmiyati ${ }^{13 *}$, Santosa $^{1}$, Irfan Dwidja Priyambada $^{2}$, Kumala Dewi $^{1}$ dan Rintawati Sandradewi ${ }^{3}$ \\ ${ }^{1}$ Fakultas Biologi, Universitas Gadjah Mada, Yogyakarta, Indonesia \\ ${ }^{2}$ Fakultas Pertanian, Universitas Gadjah Mada, Yogyakarta, Indonesia \\ ${ }^{3}$ Fakultas Biologi Universitas Kristen Satya Wacana, Salatiga, Indonesia \\ *Penulis untuk korespondensi: 0298-321212; fax: 0298-321433; e-mail: kas@staff.uksw.edu
}

\begin{abstract}
In contrast to other toxic trace metals, $\mathrm{Cr}$ has received little attention. Since valence level of chromium determines its toxicity, chromium is categorized as unique heavy metal. Chromium hexavalent $\left(\mathrm{Cr}^{6+}\right)$ has the biggest toxicity among other valence levels. Seed germination and seedling growth are sensitive to heavy metal stresses. This research aimed to find out the responses of seed germination and seedling growth of 12 sorghum varieties toward $\mathrm{Cr}^{6+}$. Seed germination and seedling growth experiment was done on 12 sorghum varieties (Badik, UPCA-1, Keris, Keris M3, hegari Genjah, Gambela, Selayer, Sangkur, Mandau, Batari, Kawali, dan Numbu), planted in petridishes with $\mathrm{Cr}^{6+}$ treatment in form of chromate $\left(\mathrm{K}_{2} \mathrm{CrO}_{4}\right)$ and dichromate $\left(\mathrm{K}_{2} \mathrm{Cr}_{2} \mathrm{O}_{7}\right)$ compounds with 0,50 and $500 \mathrm{mg}$ of $\mathrm{Cr} / \mathrm{l}$ concentration for a week. The parameters measured were the number of seeds germinate each day; the length of radicle and plumule, and fresh and dry weight at the end of experiment. The results showed that higher concentration of $\mathrm{Cr}^{6+}$ both in form of dichromate and chromate, significantly decreased the length of radicle and plumule, fresh and dry weight, and SVI (seedling vigor index) value. However, index germination (GI) value and percentage of germination of the 12 varieties sorgum significantly increased in the treatment of $50 \mathrm{mg} \mathrm{Cr} / 1 \mathrm{Cr}{ }^{6+}$ in form of dichromate and chromate. The treatment of dichromate compound showed bigger effect than chromate toward variables of seed germination and seedling growth of sorghum. It was noticed that 12 sorghum varieties possessed an integrated complex of adaptation to cope with the range of form of compound and concentration of $\mathrm{Cr}^{6+}$. Based on the responses of seed germination and seedling growth, Kawali, Hegari, Keris, Keris M3, Mandau, and Selayer varieties was more susceptible toward $\mathrm{Cr}^{6+}$ toxicity, and Sangkur, Selayer, Batari, and Numbu was more tolerant than other varieties.
\end{abstract}

Keywords : chromate, dichromate, Sorghum bicolor, seedling, hexavalent chromium

\section{PENDAHULUAN}

Polutan logam berat $\mathrm{Cr}$ di lingkungan mendapat perhatian serius karena bersifat persisten dan tidak dapat didegradasi, sehingga mengancam kehidupan tumbuhan, hewan, mikroorganisme dan bahkan kesehatan manusia (Gheju et al. 2009). Krom (Cr) merupakan salah satu logam berat toksik bagi tumbuhan, yang memiliki kemelimpahan berkisar antara $10-50 \mathrm{mg} / \mathrm{kg}$ di tanah, 0,1-117 g/l di air tawar, dan 0,2-50 g/l pada air laut (Shanker et al. 2005). Keberadaan Cr lingkungan dapat bersumber dari alam maupun aktivitas anthropogenik. Kemelimpahan $\mathrm{Cr}$ di lingkungan cenderung mengalami peningkatan dari waktu ke waktu, karena meningkatnya aktivitas manusia di bidang industri terutama penyamakan kulit, pelapisan logam (penyepuhan), tekstil, cat, tinta, pengawetan kayu, industri baja, pemakaian fungisida, dan instalasi pendinginan air (Kotas \& Stasicka, 2000).

Krom merupakan logam berat unik dibandingkan yang lain, karena tingkat valensi yang berbeda, terutama krom trivalen $\left(\mathrm{Cr}^{3+}\right)$ dan krom heksavalen $\left(\mathrm{Cr}^{6+}\right)$, menunjukkan perbedaan yang menyolok dalam hal mobilitas, kelarutan, reaktivitas dan toksisitas ( $\mathrm{Yu} \& \mathrm{Gu}, 2007)$. Ion $\mathrm{Cr}^{6+}$ bersifat lebih toksik dibandingkan $\mathrm{Cr}^{3+}$, karena toksisitasnya 10-100 kali lebih tinggi dibandingkan $\mathrm{Cr}^{3+}$. Bartlett (1991) menyatakan bahwa $\mathrm{Cr}^{6+}$ dalam bentuk kromat dan dikromat memiliki kelarutan sangat tinggi di dalam air, sedangkan $\mathrm{Cr}^{3+}$ kurang bersifat larut di dalam air dan dibutuhkan oleh hewan dalam jumlah yang sangat sedikit dalam bentuk nutrien anorganik.

Krom heksavalen merupakan bentuk krom yang sangat toksik karena berada dalam bentuk 
paling teroksidasi, reaktif, bersifat karsinogenik, mutagenik, dan teratogenik (Bartlett, 1991; Choppala et al. 2010). $\quad \mathrm{Cr}^{6+}$ juga merupakan oksidan kuat yang dapat mengubah permeabilitas membran dan mengoksidasi sel organisme, serta mampu serta mampu diserap 3-5 kali lebih banyak oleh organisme dibandingkan $\mathrm{Cr}^{3+}$ (Njoku \& Nweeze, 2009; Aquilar et al. 2008; James, 2002). Spesies krom heksavalen yang paling banyak dilaporkan toksisitasnya terhadap berbagai jenis tumbuhan adalah $\mathrm{K}_{2} \mathrm{Cr}_{2} \mathrm{O}_{7}$ (Mei et al. 2002; Zou et al. 2006; Ganesh et al. 2008; Gupta et al. 2009; Dubey et al. 2010; Malmir, 2011; Ali et al. 2011). Senyawa krom heksavalen lain yang juga telah diteliti efek toksiknya terhadap tumbuhan adalah $\mathrm{K}_{2} \mathrm{CrO}_{4}$ (Tripathi et al. 2011; Sharma et al. 2011), $\mathrm{Na}_{2} \mathrm{CrO}_{4}$ (Vasquez et al. 1987), $\mathrm{Na}_{2} \mathrm{Cr}_{2} \mathrm{O}_{7} \cdot 2 \mathrm{H}_{2} \mathrm{O}$ (Subrahmanyam, 2008) dan $\mathrm{CrO}_{3}$ (Verma et al. 2009).

Seperti logam berat lain, penyerapan dan akumulasi $\mathrm{Cr}$ dalam jaringan tumbuhan akan mempengaruhi pertumbuhan dan aktivitas fisiologis. Salah satu proses pertumbuhan yang dipengaruhi adalah perkecambahan. Toksisitas krom menyebabkan penghambatan perkecambahan dan pertumbuhan kecambah, pertumbuhan dan perkembangan akar, batang dan daun (Shanker et al. 2005). Krom telah dilaporkan mempengaruhi perkecambahan biji pada 8 kultivar dari Vigna radiata (Rout et al. 1997) dan pada beberapa kultivar padi (Gyawali dan Lekhak, 2006).

Tanaman Sorghum bicolor merupakan anggota famili Poaceae yang dapat dimanfaatkan sebagai bahan pangan dan pakan. Sorgum juga dapat dimanfaatkan bahan baku untuk media jamur merang, industri alkohol, industri gula, asam amino, monosodium glutamat (MSG), bahan baku etanol, bahan baku untuk lem, dan sapu (Yusro, 2001; Sirappa, 2003). Sorgum memiliki adaptasi agroekologi luas, dapat ditanam pada hampir semua jenis lahan, baik subur mupun lahan kering (marjinal), memiliki daya adaptasi tinggi terhadap berbagai kondisi cekaman, seperti kekeringan, suhu tinggi, salinitas, genangan. Oleh karena itu tanaman sorgum sangat potensial untuk diteliti responnya terhadap cekaman logam berat, salah satunya logam berat krom, karena menurut Jamali et al. (2008) dan Revathi et al. (2011) melaporkan
Sorghum bicolor merupakan salah satu jenis tanaman akumulator logam berat Cr. Tujuan penelitian ini adalah mengetahui respon perkecambahan dan pertumbuhan kecambah dari 12 varietas sorgum yang ada di Indonesia terhadap cekaman $\mathrm{Cr}$ heksavalen $\left(\mathrm{Cr}^{6+}\right)$.

\section{BAHAN DAN METODE}

\section{Penyiapan Benih Sorgum dan Perlakuan $\mathrm{Cr}$}

Penelitian dilakukan secara eksperimental menggunakan rancangan acak lengkap dengan 3 faktor yaitu bentuk senyawa $\mathrm{Cr}^{6+}$, konsentrasi $\mathrm{Cr}^{6+}$ dan varietas sorgum. Ada 2 bentuk senyawa $\mathrm{Cr}^{6+}$ yang digunakan perlakuan yaitu $\mathrm{K}_{2} \mathrm{CrO}_{4}$ dan $\mathrm{K}_{2} \mathrm{Cr}_{2} \mathrm{O}_{7}$, dengan 3 aras konsentrasi $\mathrm{Cr}$ yaitu 0 (kontrol), 50 dan $500 \mathrm{mg} \mathrm{Cr} / 1$. Perlakuan varietas terdiri dari 12 varietas sorgum. Sepuluh varietas diperoleh dari BB Biogen (Bogor) meliputi Badik, UPCA-1, Keris, Keris M3, Hegari Genjah, Gambela, Selayer, Sangkur, Mandau, dan Batari, sedangkan 2 varietas dari Balitsereal (Maros, Sulawesi Selatan) yaitu Kawali dan Numbu. Respon perkecambahan dan pertumbuhan kecambah dari 12 varietas sorgum terhadap perlakuan $\mathrm{Cr}^{6+}$ diamati dengan cara mengecambahkan biji selama 1 minggu. Sebanyak 50 biji untuk tiap varietas, disterilisasi menggunakan larutan pemutih komersial mengandung natrium hipoklorid $(\mathrm{NaClO}) \quad 0,5 \%$ selama 10 menit, dibilas dengan akuades steril sebanyak 3 kali, selanjutnya direndam dalam akuades steril selama 4-5 jam untuk mempercepat perkecambahan biji. Perlakuan krom diberikan bersama-sama dengan larutan Hoagland yang digunakan untuk membasahi benih sebanyak $20 \mathrm{ml}$ pada awal perkecambahan dan ditambah $5 \mathrm{ml}$ setiap hari selama 7 hari, dan larutan Hoagland tanpa perlakuan $\mathrm{Cr}$ digunakan sebagai kontrol. Komposisi media Hoagland yang digunakan mengandung $\mathrm{KNO}_{3} 606,6, \mathrm{Ca}\left(\mathrm{NO}_{3}\right)_{2} .5 \mathrm{H}_{2} \mathrm{O} 1270$, $\mathrm{NaCl} 58,4, \mathrm{KH}_{2} \mathrm{PO}_{4} 272,2, \mathrm{MgSO}_{4} .7 \mathrm{H}_{2} \mathrm{O}$ 492,8, $\mathrm{MnCl}_{2} \quad 1,158, \quad \mathrm{ZnSO}_{4} \quad 0,123, \quad \mathrm{H}_{3} \mathrm{BO}_{3} \quad 2,86$, $\mathrm{CuSO}_{4} .5 \mathrm{H}_{2} \mathrm{O} 0,08, \mathrm{H}_{2} \mathrm{MoO}_{4}$ 0,017 dan Fe-EDTA 5,0 . Setiap perlakuan dengan 5 ulangan.

\section{Uji Perkecambahan Biji Sorgum}

Sebanyak 10 biji tiap varietas dikecambahkan di dalam cawan petri yang telah diberi alas kertas merang dan dijaga agar selalu 
tetap basah dengan setiap hari diberi penambahan larutan $\mathrm{Cr}$ sesuai perlakuan dan akuades pada perlakuan kontrol dengan volume konstan per harinya. Perkecambahan biji dilakukan dalam kondisi gelap, pada suhu $25 \pm 2{ }^{\circ} \mathrm{C}$. Parameter yang diamati setiap hari adalah banyaknya jumlah biji yang berkecambah selama 7 hari. Biji dikatakan berkecambah bila radikulanya telah tumbuh memanjang sebesar $\pm 2 \mathrm{~mm}$. Pertumbuhan kecambah meliputi panjang radikula, panjang plumula, panjang kecambah, berat basah dan berat kering kecambah diukur pada akhir perkecambahan. Hasil penghitungan jumlah biji yang berkecambah setiap hari dan pengamatan pertumbuhan kecambah pada akhir perkecambahan digunakan untuk menentukan persentase perkecambahan, indeks perkecambahan (GI, Germination Index), dan indeks vigor kecambah (SVI, Seedling Vigor Index) dengan rumus seperti yang tercantum pada Tabel 1 .

Tabel 1 Rumus untuk penghitungan nilai indeks parameter perkecambahan

\begin{tabular}{|c|c|c|c|}
\hline $\begin{array}{c}\text { Parameter } \\
\text { Perkecambahan }\end{array}$ & Rumus & Keterangan & Referensi \\
\hline $\begin{array}{l}\text { Persentase } \\
\text { perkecambahan (PKC) }\end{array}$ & $\sum \mathrm{Bk} / \Sigma \mathrm{TB} \times 100$ & $\begin{array}{l}\sum \mathrm{Bk}=\text { jumlah biji berkecambah } \\
\sum \mathrm{TB}=\text { jumlah total biji }\end{array}$ & Talukdar (2011) \\
\hline $\begin{array}{l}\text { Indeks perkecambahan } \\
\text { (GI) }\end{array}$ & $\Sigma \mathbf{G t} / \sum \mathbf{T t}$ & $\begin{array}{l}\sum \mathrm{Gt}=\text { jumlah total biji berkecambah pada hari } \mathrm{t} \\
\sum \mathrm{Tt}=\text { jumlah total hari perkecambahan pada hari } \mathrm{t}\end{array}$ & Carpici et al. (2009) \\
\hline $\begin{array}{l}\text { Indeks vigor kecambah } \\
\text { (SVI) }\end{array}$ & PKC x PjK & $\begin{array}{l}\mathrm{PKC}=\% \text { perkecambahan } \\
\mathrm{PjK}=\text { panjang kecambah }(\mathrm{cm})\end{array}$ & Jahangir et al. (2009) \\
\hline
\end{tabular}

\section{Analisis Data}

Data pengamatan dianalisis secara statistik dengan analisis sidik ragam (ANOVA) menggunakan program $S A S$. Hasil analisis varian dari parameter yang berbeda nyata diuji lanjut menggunakan Duncan Multiple Range Test (DMRT) taraf uji 5\% untuk mengetahui beda nyata di antara rerata perlakuan atau kombinasi perlakuan.

\section{HASIL DAN PEMBAHASAN}

Hasil analisis sidik ragam terhadap variabel perkecambahan dan pertumbuhan kecambah dari 12 varietas sorgum ditampilkan pada Tabel 2. Ada 8 variabel yang dianalisis meliputi panjang akar, panjang plumula, panjang kecambah, berat basah kecambah, berat kering kecambah, nilai SVI, persentase perkecambahan, dan indeks perkecambahan.

Tabel 2. Analisis sidik ragam variabel perkecambahan

\begin{tabular}{|c|c|c|c|c|c|c|c|c|c|}
\hline \multirow{2}{*}{$\begin{array}{l}\text { Sumber } \\
\text { keragaman }\end{array}$} & \multirow[t]{2}{*}{$\mathbf{d b}$} & \multicolumn{8}{|c|}{ F hitung } \\
\hline & & PjR & $\mathbf{P j P}$ & $\mathbf{P j K}$ & BBK & BKK & SVI & PKC & GI \\
\hline Varietas & 11 & $16,51^{* *}$ & $16,61 * *$ & $11,58^{* *}$ & $32,26^{* *}$ & $17,21^{* *}$ & $15,96^{* *}$ & $37,39 * *$ & $63,74 * *$ \\
\hline $\mathrm{PCr}$ & 2 & $1239,43 * *$ & $482,81 * *$ & $943,60 * *$ & $434,89 * *$ & $229,02 * *$ & $807,99 * *$ & $0,13 \mathrm{~ns}$ & $0,94 \mathrm{~ns}$ \\
\hline Varietas*PCr & 22 & $9,96 * *$ & $3,46^{* *}$ & $5,02 * *$ & $8,70 * *$ & $6,58 * *$ & $9,16^{* *}$ & $2,79 * *$ & $2,55^{* *}$ \\
\hline KONS & 1 & $150,46 * *$ & $580,48 * *$ & $390,77 * *$ & $156,24 * *$ & $253,42 * *$ & $105,3^{* *} 1$ & $16,76^{* *}$ & $133,01 * *$ \\
\hline Varietas*KONS & 11 & $2,75 \mathrm{~ns}$ & $4,32 * *$ & $1,89 *$ & $1,67 \mathrm{~ns}$ & $3,25 * *$ & $2,04 *$ & $1,63 \mathrm{~ns}$ & $1,34 \mathrm{~ns}$ \\
\hline PCr*KONS & 1 & $1,45 \mathrm{~ns}$ & $22,53 * *$ & $10,57 * *$ & $0,81 \mathrm{~ns}$ & $0,33 \mathrm{~ns}$ & $0,40 \mathrm{~ns}$ & $13,42 * *$ & $12,85 * *$ \\
\hline Varietas*PCr*KONS & 11 & $0,82 \mathrm{~ns}$ & $1,45 \mathrm{~ns}$ & $0,62 \mathrm{~ns}$ & $0,82 \mathrm{~ns}$ & $1,44 \mathrm{~ns}$ & $0,74 \mathrm{~ns}$ & $2,64 * *$ & $1,57 \mathrm{~ns}$ \\
\hline Galat & 240 & & & & & & & & \\
\hline Total & 299 & & & & & & & & \\
\hline Koefisien keragaman & & $37,79 \%$ & $23,09 \%$ & $26,41 \%$ & $17,75 \%$ & $28,57 \%$ & $45,88 \%$ & $14,90 \%$ & $18,62 \%$ \\
\hline
\end{tabular}

Keterangan : **, *, dan tn masing-masing adalah sangat nyata pada batas peluang 0,$01 ;$ nyata pada batas peluang 0,05 dan tidak nyata; $\mathrm{db}=$ derajat bebas, $\mathrm{PCr}=$ perlakuan bentuk senyawa $\mathrm{Cr}^{6+}, \mathrm{KONS}=$ konsentrasi $\mathrm{Cr}^{6+}, \mathrm{PjR}=$ panjang radikula, $\mathrm{PjP}=$ panjang plumula, $\mathrm{PjK}=$ panjang kecambah, $\mathrm{BBK}=$ berat basah kecambah, $\mathrm{BKK}=$ berat kering kecambah, $\mathrm{SVI}=$ seedling vigor index, $\mathrm{PKC}=$ persentase perkecambahan, $\mathrm{GI}=$ germination index 
Lingkungan tumbuh mempengaruhi secara nyata perkecambahan sorgum. Varietas sorgum yang diuji menunjukkan respon perkecambahan dan pertumbuhan kecambah yang berbeda terhadap perlakuan $\mathrm{Cr}^{6+}$ baik dalam bentuk senyawa dikromat $\left(\mathrm{K}_{2} \mathrm{Cr}_{2} \mathrm{O}_{7}\right)$ maupun kromat $\left(\mathrm{K}_{2} \mathrm{CrO}_{4}\right)$ pada konsentrasi 50 dan $500 \mathrm{mg} \mathrm{Cr} / \mathrm{l}$, hal ini ditunjukkan adanya interaksi antara varietas dengan perlakuan bentuk senyawa dan konsentrasi $\mathrm{Cr}^{6+}$. Interaksi secara nyata tersebut ditunjukkan pada variabel panjang akar, panjang plumula, panjang kecambah, berat basah kecambah, berat kering kecambah, nilai SVI, persentase perkecambahan, maupun nilai indeks perkecambahan. Peralta et al. (2001) berdasarkan hasil penelitiannya melaporkan bahwa fase perkecambahan biji merupakan proses fisiologis pertama yang dipengaruhi oleh logam berat $\mathrm{Cr}$, dan kemampuan biji untuk berkecambah di dalam media mengandung $\mathrm{Cr}$ dapat digunakan sebagai indikator tingkat toleransinya terhadap logam tersebut.

Hasil penelitian (Tabel 3 dan Gambar 1) menunjukkan bahwa faktor varietas, bentuk senyawa dan konsentrasi $\mathrm{Cr}^{6+}$, mempengaruhi secara nyata perkecambahan dan pertumbuhan kecambah dari varietas sorgum yang diuji. Semakin tinggi konsentrasi $\mathrm{Cr}^{6+}$ yang diberikan baik dalam bentuk dikromat maupun kromat maka panjang akar, panjang plumula, panjang kecambah, berat basah kecambah, berat kering kecambah, dan nilai SVI akan semakin menurun. Namun pada variabel persentase dan nilai indeks perkecambahan, perlakuan $\mathrm{Cr}^{6+}$ terutama pada konsentrasi $50 \mathrm{mg} \mathrm{Cr} / 1$ tidak selalu menurunkan nilai kedua variabel tersebut pada keduabelas varietas sorgum, sebaliknya cenderung meningkatkan. Hasil ini diperkuat oleh Zayed dan Terry (2003) yang menyatakan bahwa Cr dalam konsentrasi tinggi dapat menghambat perkecambahan biji dan pertumbuhan kecambah. Efek penghambatan $\mathrm{Cr}$ terhadap perkecambahan biji lebih kecil dibandingkan pertumbuhan kecambah. Corradi et al. (1993) melaporkan bahwa perkecambahan biji Salvia sclarea secara in vitro tidak dipengaruhi oleh $\mathrm{Cr}$ dalam bentuk $\mathrm{K}_{2} \mathrm{Cr}_{2} \mathrm{O}_{7}$ (dikromat), namun radikula yang muncul dan terpapar oleh $\mathrm{Cr}$ dalam media mengalami penghambatan pertumbuhan.

Tabel 3 Nilai rata-rata variabel perkecambahan dan pertumbuhan kecambah dari 12 varietas sorgum pada perlakuan bentuk senyawa dan konsentrasi $\mathrm{Cr}^{6+}$

\begin{tabular}{|c|c|c|c|c|c|c|c|c|}
\hline PERLAKUAN & $\begin{array}{c}\mathrm{Pj} \mathrm{R} \\
\mathrm{cm}\end{array}$ & $\begin{array}{l}\mathrm{PjP} \\
\mathrm{cm}\end{array}$ & $\begin{array}{c}\mathrm{PjK} \\
\mathrm{cm}\end{array}$ & $\begin{array}{c}\text { BBK } \\
\mathrm{g}\end{array}$ & $\begin{array}{c}\text { BKK } \\
\mathrm{g}\end{array}$ & SVI & $\mathrm{PKC}$ & GI \\
\hline \multicolumn{9}{|l|}{ Varietas } \\
\hline UPCA & $2,39 \mathrm{e}$ & 4,80 ef & $7,18 \mathrm{c}$ & $0,989 \mathrm{~b}$ & $0,057 \mathrm{de}$ & $197,69 \mathrm{de}$ & $80,25 \mathrm{~cd}$ & $13,46 \mathrm{de}$ \\
\hline Badik & $2,52 \mathrm{e}$ & 5,33 cde & $7,85 \mathrm{bc}$ & $0,874 \mathrm{c}$ & $0,062 \mathrm{bcd}$ & 210,18 cde & $84,01 \mathrm{bc}$ & $12,53 \mathrm{e}$ \\
\hline Keris & $2,63 \mathrm{e}$ & $5,67 \mathrm{~cd}$ & $8,30 \mathrm{bc}$ & $0,772 \mathrm{~d}$ & $0,064 \mathrm{bcd}$ & $239,39 \mathrm{~cd}$ & $87,68 \mathrm{ab}$ & $15,01 \mathrm{bc}$ \\
\hline Keris M3 & $4,85 \mathrm{a}$ & $5,00 \mathrm{de}$ & $9,84 \mathrm{a}$ & $0,998 \mathrm{~b}$ & $0,062 \mathrm{bcd}$ & $435,71 \mathrm{a}$ & $91,38 \mathrm{a}$ & $16,44 \mathrm{a}$ \\
\hline Hegari & $2,68 \mathrm{e}$ & 4,80 ef & $7,48 \mathrm{c}$ & $0,796 \mathrm{~cd}$ & $0,063 \mathrm{bcd}$ & $181,10 \mathrm{de}$ & $64,82 \mathrm{e}$ & $8,52 \mathrm{f}$ \\
\hline Sangkur & $2,87 \mathrm{de}$ & 5,33 cde & $8,21 \mathrm{bc}$ & $0,848 \mathrm{~cd}$ & 0,058 cde & $241,38 \mathrm{~cd}$ & $75,14 \mathrm{~d}$ & $14,02 \mathrm{~cd}$ \\
\hline Mandau & $3,89 \mathrm{bc}$ & $4,09 \mathrm{f}$ & $7,98 \mathrm{bc}$ & $1,002 \mathrm{~b}$ & $0,081 \mathrm{a}$ & $321,59 \mathrm{~b}$ & $79,37 \mathrm{~cd}$ & $16,15 \mathrm{ab}$ \\
\hline Numbu & $3,42 \mathrm{~cd}$ & $6,42 \mathrm{ab}$ & $9,84 \mathrm{a}$ & $1,320 \mathrm{a}$ & $0,069 \mathrm{~b}$ & $277,95 \mathrm{bc}$ & $79,47 \mathrm{~cd}$ & 13,75 cde \\
\hline Gambela & $2,44 \mathrm{e}$ & $5,76 \mathrm{bc}$ & $8,21 \mathrm{bc}$ & $1,005 \mathrm{~b}$ & $0,068 \mathrm{bc}$ & 213,76 cde & $84,84 \mathrm{abc}$ & $15,64 a b$ \\
\hline Kawali & $1,36 \mathrm{f}$ & $3,07 \mathrm{~g}$ & $4,43 \mathrm{~d}$ & $0,608 \mathrm{e}$ & $0,024 \mathrm{f}$ & $93,83 \mathrm{f}$ & $62,43 \mathrm{e}$ & $9,56 \mathrm{f}$ \\
\hline Selayer & $3,07 \mathrm{de}$ & $6,50 \mathrm{a}$ & $9,57 \mathrm{a}$ & $0,791 \mathrm{~cd}$ & $0,049 \mathrm{e}$ & $237,82 \mathrm{~cd}$ & $74,35 \mathrm{~d}$ & $9,09 \mathrm{f}$ \\
\hline Batari & $4,12 \mathrm{~b}$ & 4,80 ef & $8,92 \mathrm{ab}$ & $0,767 \mathrm{~d}$ & $0,050 \mathrm{e}$ & $157,17 \mathrm{e}$ & $40,73 \mathrm{f}$ & $4,38 \mathrm{~g}$ \\
\hline \multicolumn{9}{|c|}{ Konsentrasi Cr (mg Cr/l) } \\
\hline 0 & $9,58 \mathrm{p}$ & $9,35 \mathrm{p}$ & $18,93 \mathrm{q}$ & $1,440 \mathrm{p}$ & $0,100 \mathrm{p}$ & $732,40 \mathrm{p}$ & $77,92 \mathrm{p}$ & $14,04 \mathrm{p}$ \\
\hline 50 & $2,28 \mathrm{q}$ & $5,92 \mathrm{q}$ & $8,20 \mathrm{q}$ & $0,890 \mathrm{q}$ & $0,066 \mathrm{q}$ & $180,41 \mathrm{q}$ & $77,07 \mathrm{p}$ & $13,68 \mathrm{p}$ \\
\hline
\end{tabular}




\begin{tabular}{lcccccccc}
500 & $0,48 \mathrm{r}$ & $2,24 \mathrm{r}$ & $2,71 \mathrm{r}$ & $0,634 \mathrm{r}$ & $0,031 \mathrm{r}$ & $38,32 \mathrm{r}$ & $71,98 \mathrm{q}$ & $10,25 \mathrm{q}$ \\
\hline \multicolumn{7}{l}{ Bentuk Senyawa Cr } & \multicolumn{7}{c}{} \\
\hline $\mathrm{K}_{2} \mathrm{CrO}_{4}$ & $4,17 \mathrm{x}$ & $6,05 \mathrm{x}$ & $10,21 \mathrm{x}$ & $0,999 \mathrm{x}$ & $0,068 \mathrm{x}$ & $320,32 \mathrm{x}$ & $75,45 \mathrm{x}$ & $12,56 \mathrm{x}$ \\
$\mathrm{K}_{2} \mathrm{Cr}_{2} \mathrm{O}_{7}$ & $1,30 \mathrm{y}$ & $3,76 \mathrm{y}$ & $5,05 \mathrm{y}$ & $0,745 \mathrm{y}$ & $0,045 \mathrm{y}$ & $104,44 \mathrm{y}$ & $75,21 \mathrm{x}$ & $12,11 \mathrm{x}$ \\
\hline
\end{tabular}

Keterangan: angka yang diikuti dengan huruf yang sama pada tiap kolom untuk tiap parameter dan perlakuan menunjukkan tidak beda nyata pada uji Duncan dengan tingkat signifikansi $5 \%, \mathrm{PjR}=$ panjang radikula, $\mathrm{PjH}=$ panjang plumula, $\mathrm{Pj} \mathrm{P}=$ panjang kecambah, $\mathrm{BBK}=$ berat basah kecambah, $\mathrm{BKK}=$ berat kering kecambah, $\mathrm{SVI}=$ seedling vigor index, $\mathrm{PKC}=$ persentase perkecambahan, $\mathrm{GI}=$ germination index

Senyawa $\mathrm{Cr}^{6+}$ dalam bentuk dikromat $\left(\mathrm{K}_{2} \mathrm{Cr}_{2} \mathrm{O}_{7}\right)$ menunjukkan efek lebih besar terhadap variabel perkecambahan dan pertumbuhan kecambah, apabila dibandingkan kromat $\left(\mathrm{K}_{2} \mathrm{CrO}_{4}\right)$, kecuali terhadap variabel persentase dan indeks perkecambahan. Hasil ini didukung oleh Samantaray et al. (1998) yang menyatakan bahwa urutan toksisitas $\mathrm{Cr}$ berdasarkan bentuk ionnya adalah sebagai berikut kromit $<$ kromat $<$ dikromat
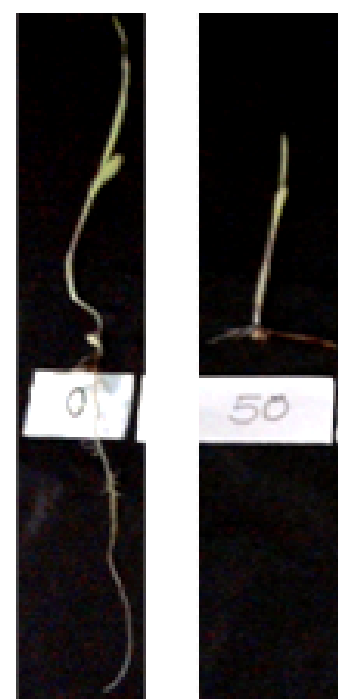

Kontrol
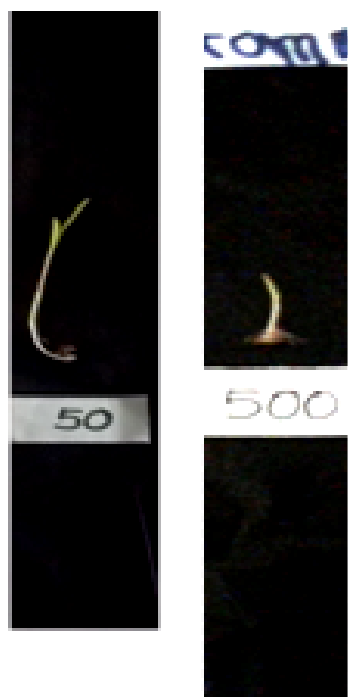

$\mathrm{K}_{2} \mathrm{Cr}_{2} \mathrm{O}_{7}$

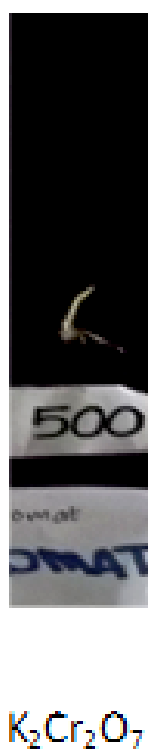

$\mathrm{K}_{2} \mathrm{Cr}_{2} \mathrm{O}_{7}$

Gambar 1. Respon pertumbuhan kecambah dari varietas sorgum terhadap perlakuan bentuk senyawa $\left(\mathrm{K}_{2} \mathrm{CrO}_{4}\right.$ dan $\mathrm{K}_{2} \mathrm{Cr}_{2} \mathrm{O}_{7}$ ) dan konsentrasi $\mathrm{Cr}^{6+}(50$ dan $500 \mathrm{mg} \mathrm{Cr} / \mathrm{l})$ 


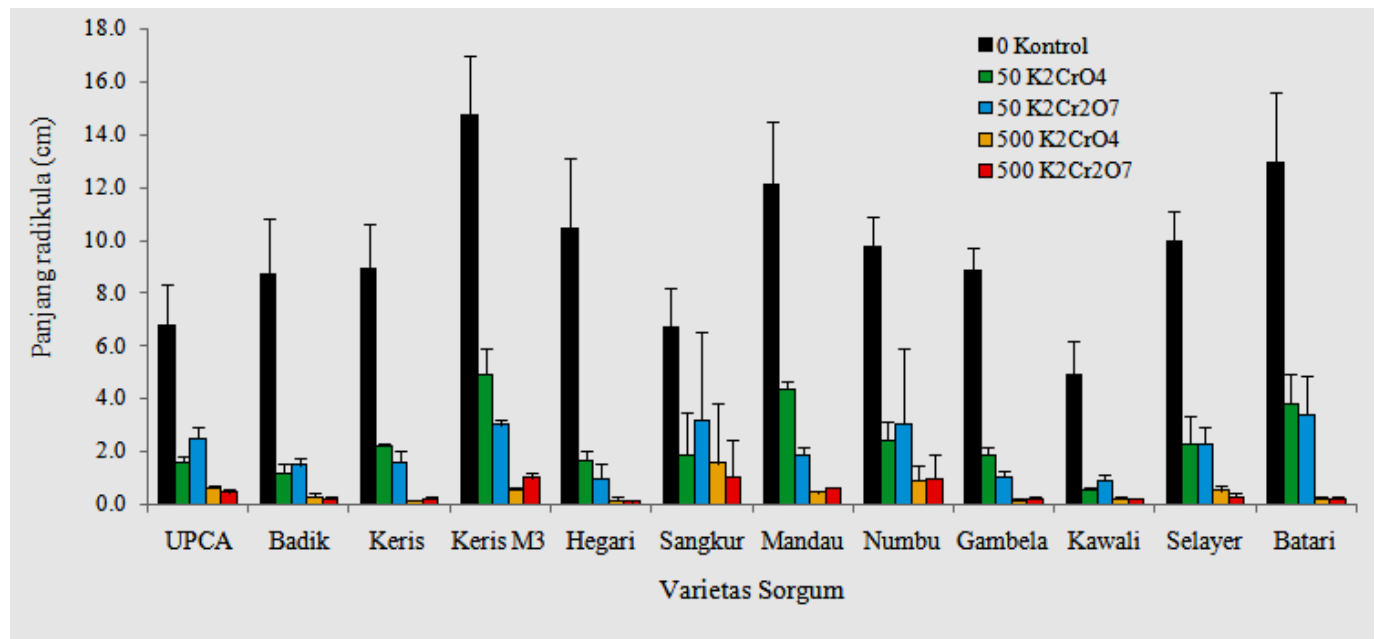

Gambar 1. Panjang radikula dari 12 varietas sorgum pada perlakuan bentuk dan konsentrasi $\mathrm{Cr}^{6+}\left(\mathrm{K}_{2} \mathrm{CrO}_{4}\right.$ dan $\mathrm{K}_{2} \mathrm{Cr}_{2} \mathrm{O}_{7}$ )

Keduabelas varietas sorgum yang diuji menunjukkan panjang radikula beragam pada perlakuan bentuk senyawa dan konsentrasi $\mathrm{Cr}^{6+}$ (Gambar 1). Pada perlakuan $\mathrm{Cr}^{6+}$ sebesar $50 \mathrm{mg}$ $\mathrm{Cr} / \mathrm{l}$, baik senyawa kromat maupun dikromat menurunkan secara nyata panjang radikula dibandingkan kontrol, dengan penurunan rata-rata mencapai $77 \%$ (berkisar antara 52,1 - 90,5\%). Pada perlakuan kromat $50 \mathrm{mg} \mathrm{Cr} / \mathrm{l}$, varietas yang paling besar mengalami penurunan panjang radikula adalah Kawali $(88,64 \%)$, dan paling kecil adalah varietas Mandau (64,22\%). Perlakuan dikromat $50 \mathrm{mg} \mathrm{Cr} / 1$ menurunkan panjang radikula paling besar pada varietas Hegari mencapai 90,45\%, paling kecil pada Sangkur (52,09\%). Rata-rata penurunan panjang radikula keduabelas varietas sorgum pada perlakuan kromat dan dikromat sebesar $500 \mathrm{mg} \mathrm{Cr} / \mathrm{l}$ mencapai $95 \%$ (berkisar antara 76,6 - 98,9\%). Varietas Sangkur mengalami penurunan panjang radikula paling kecil pada perlakuan kromat dan dikromat $500 \mathrm{mg}$ $\mathrm{Cr} / 1$ yaitu berturut-turut sebesar 76,57 dan 84,33\%, sedangkan varietas Hegari mengalami penurunan paling besar yaitu sebesar 98,57 dan 98,95\%. Efek $\mathrm{Cr}^{6+}$ terhadap penghambatan pertumbuhan radikula dilaporkan juga pada Cucumis sativus (Verma et al., 2009), Oryza sativa (Gyawali dan Lekhak, 2006) dan Triticum aestivum (Datta et al. 2011)

Perlakuan $\mathrm{Cr}^{6+}$ baik dalam bentuk kromat maupun dikromat sebesar 50 dan $500 \mathrm{mg} \mathrm{Cr} / 1$ menurunkan secara nyata panjang plumula pada 12 varietas sorgum yang diuji (Gambar 2). Panjang plumula di antara varietas menunjukkan perbedaan secara nyata. Penurunan panjang plumula di antara 12 varietas juga beragam. Pada perlakuan konsentrasi $\mathrm{Cr}^{6+}$ (kromat dan dikromat) sebesar 50 $\mathrm{mg} \mathrm{Cr} / 1$, rata-rata penurunan panjang plumula dari 12 varietas mencapai $36,72 \%$ yaitu berkisar antara $2,7-67,7 \%$, sedangkan pada konsentrasi $500 \mathrm{mg}$ $\mathrm{Cr} / 1$ mencapai $76,01 \%$ (berkisar antara 62,3 $87,6 \%$ ). Senyawa dikromat menurunkan panjang plumula lebih besar dan berbeda nyata dengan kromat baik pada konsentrasi 50 maupun $500 \mathrm{mg}$ $\mathrm{Cr} / 1$. 


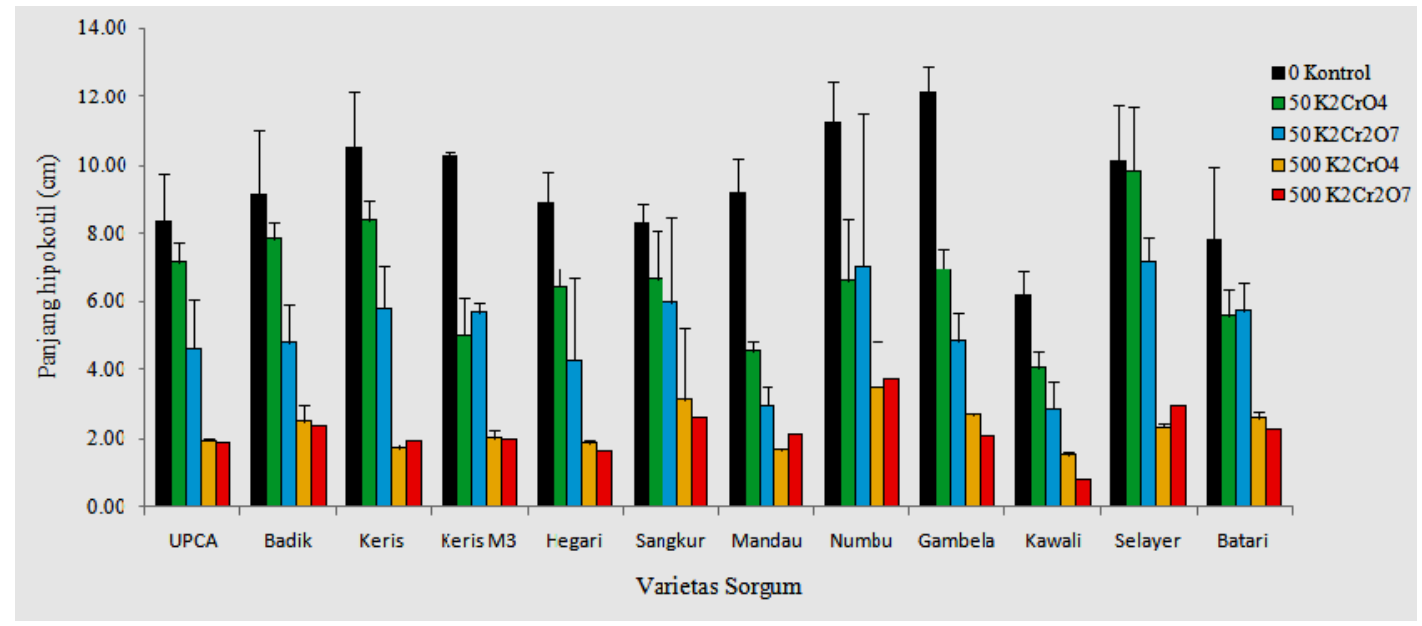

Gambar 2. Panjang plumula dari 12 varietas sorgum pada perlakuan bentuk dan konsentrasi $\mathrm{Cr}^{6+}$ $\left(\mathrm{K}_{2} \mathrm{CrO}_{4}\right.$ dan $\left.\mathrm{K}_{2} \mathrm{Cr}_{2} \mathrm{O}_{7}\right)$

Respon panjang plumula varietas Selayer dan Batari menunjukkan penurunan paling kecil berturut-turut pada perlakuan kromat dan dikromat $50 \mathrm{mg} \mathrm{Cr} / \mathrm{l}$, dengan persentase penurunan sebesar 2,71 dan $27,03 \%$. Sedangkan varietas yang mengalami penurunan paling besar adalah Keris M3 (50,99\%) dan Mandau (67,68\%), berturut-turut pada perlakuan kromat dan dikromat. Pada perlakuan $\mathrm{Cr}$ sebesar $500 \mathrm{mg} \mathrm{Cr} / \mathrm{l}$, varietas Sangkur memiliki penurunan paling kecil $(62,33 \%)$ dan varietas Keris mengalami penurunan paling besar $(83,44 \%)$ pada perlakuan senyawa kromat. Sedangkan pada perlakuan senyawa dikromat, penurunan panjang plumula paling besar dijumpai pada varietas Kawali $(87,61 \%)$ dan paling kecil pada varietas Numbu $(66,83 \%)$. Selain menurunkan panjang radikula, $\mathrm{Cr}$ juga menghambat pertumbuhan plumula. Bishnoi et al. (1993) melaporkan bahwa perlakuan $\mathrm{Cr}^{6+}$ dalam bentuk dikromat pada konsentrasi lebih besar dari $0,5 \mathrm{mM}$ menghambat secara nyata baik pertumbuhan radikula maupun plumula.

Berdasarkan hasil pada Gambar 3 ditunjukkan bahwa respon panjang kecambah dari 12 varietas sorgum yang diuji berbeda nyata antara kontrol dengan perlakuan $\mathrm{Cr}^{6+}$. Perlakuan $\mathrm{Cr}^{6+}$ baik dalam bentuk kromat maupun dikromat sebesar 50 dan $500 \mathrm{mg} \mathrm{Cr} / 1$ menurunkan secara nyata panjang kecambah pada 12 varietas sorgum yang diuji. Keduabelas varietas sorgum menunjukkan penurunan panjang kecambah beragam pada perlakuan bentuk senyawa dan konsentrasi $\mathrm{Cr}^{6+}$. Perlakuan $\mathrm{Cr}^{6+}$ (kromat dan dikromat) sebesar $50 \mathrm{mg} \mathrm{Cr} / \mathrm{l}$, rata-rata penurunan panjang plumula dari 12 varietas mencapai $56,40 \%$ dengan kisaran antara 38,7 - 77,2\%, sedangkan pada konsentrasi $500 \mathrm{mg} \mathrm{Cr} / 1$ mencapai $68,72 \%$ (berkisar antara 68,7 - 91,2\%). Pada perlakuan $\mathrm{Cr}^{6+}$ sebesar $50 \mathrm{mg} \mathrm{Cr} / 1$ menyebabkan penurunan panjang kecambah paling besar pada varietas Keris M3 (kromat) dan Mandau (dikromat) masing-masing berturut-turut sebesar 60,14 dan $77,17 \%$. Penurunan paling kecil dijumpai pada varietas Selayer (kromat) dan Sangkur, berturut-turut sebesar 39,70 dan 38,72\%. Pada perlakuan $\mathrm{Cr}$ sebesar $500 \mathrm{mg} \mathrm{Cr} / \mathrm{l}$ penurunan panjang kecambah paling besar dijumpai pada varietas Keris (kromat) dan Kawali (dikromat) yaitu berturut-turut sebesar 90,43 dan 91,24\%, serta paling kecil dijumpai pada varietas Sangkur (perlakuan kromat dan dikromat) yaitu berturutturut sebesar 68,72 dan 75,53\%. Penurunan pertumbuhan panjang kecambah akibat perlakuan $\mathrm{Cr}^{6+}$ disebabkan $\mathrm{Cr}$ merupakan logam berat non essensial yang bersifat toksik. Menurut Verma et al. (2009) kecambah yang terpapar logam dalam konsentrasi tinggi akan mengalami penghambatan metabolisme dan pertumbuhan sebagai akibat adanya penghambatan penyerapan nutrien oleh radikula. Liu et al. (1993) melaporkan bahwa 
penghambatan pertumbuhan kecambah dapat juga disebabkan oleh adanya penghambatan pembelahan dan pemanjangan sel akibat terjadinya aberasi kromosom.

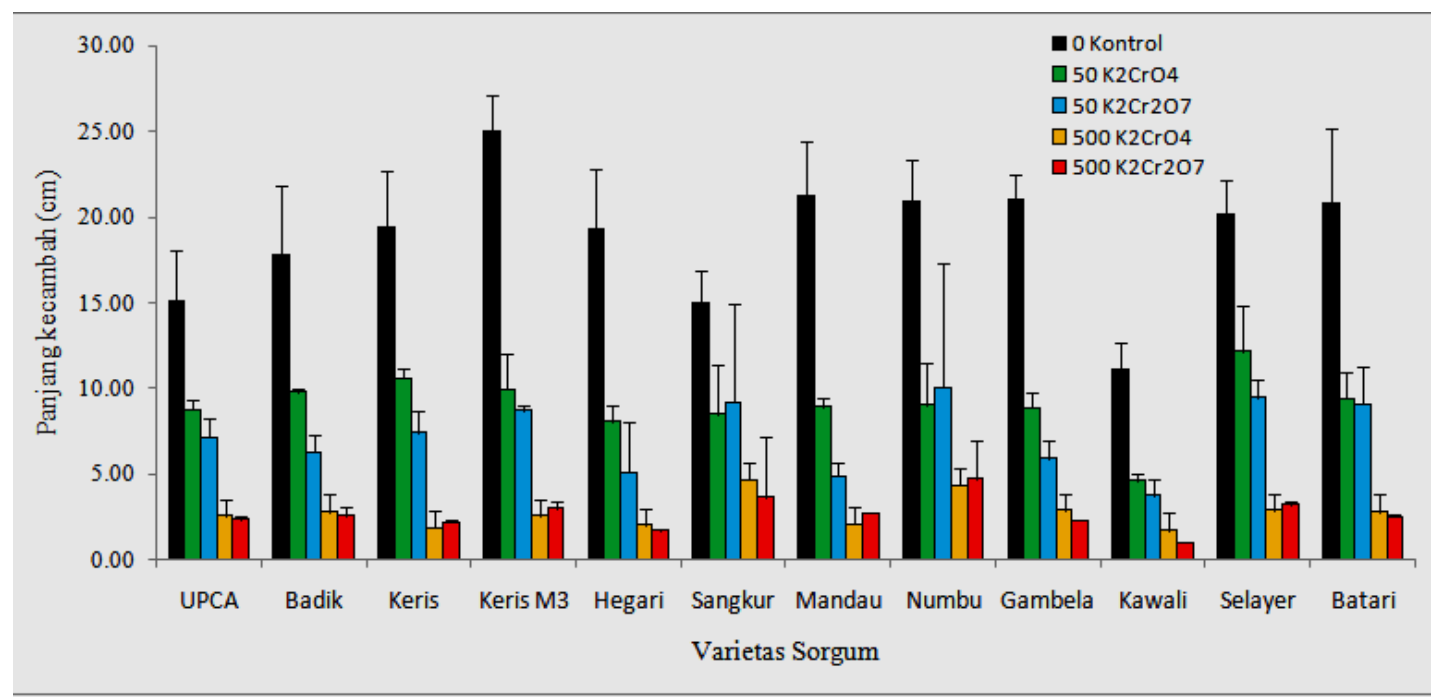

Gambar 3. Panjang kecambah dari 12 varietas sorgum pada perlakuan bentuk dan konsentrasi $\mathrm{Cr}^{6+}\left(\mathrm{K}_{2} \mathrm{CrO}_{4}\right.$ dan $\mathrm{K}_{2} \mathrm{Cr}_{2} \mathrm{O}_{7}$ )

Respon 12 varietas sorgum terhadap perlakuan $\mathrm{Cr}^{6+}$ (kromat dan dikromat) pada konsentrasi 50 dan $500 \mathrm{mg} \mathrm{Cr} / 1$ juga ditunjukkan oleh adanya penurunan biomassa kecambah baik basah (Gambar 4) maupun kering (Gambar 5). Penurunan biomassa basah dan kering kecambah paling tinggi pada perlakuan $\mathrm{Cr}$ sebesar $500 \mathrm{mg}$ $\mathrm{Cr} / \mathrm{l}$ dengan rata-rata mencapai 54,07\% (berat basah) dan 31,08\% (berat kering). Pada konsentrasi $50 \mathrm{mg} \mathrm{Cr} / \mathrm{l}$, rata-rata penurunan biomassa dari 12 varietas sorgum mencapai $36,36 \%$ (berat basah) dan 31,08\% (berat kering). Senyawa $\mathrm{Cr}^{6+}$ dalam bentuk kromat pada konsentrasi $50 \mathrm{mg} \mathrm{Cr} / \mathrm{l}$ menurunkan rata-rata biomassa basah dan kering kecambah 12 varietas sorgum lebih tinggi dibandingkan dikromat, sebaliknya pada konsentrasi $500 \mathrm{mg} \mathrm{Cr} / 1$, dikromat menurunkan biomassa basah dan kering kecambah lebih tinggi dibandingkan kromat. 


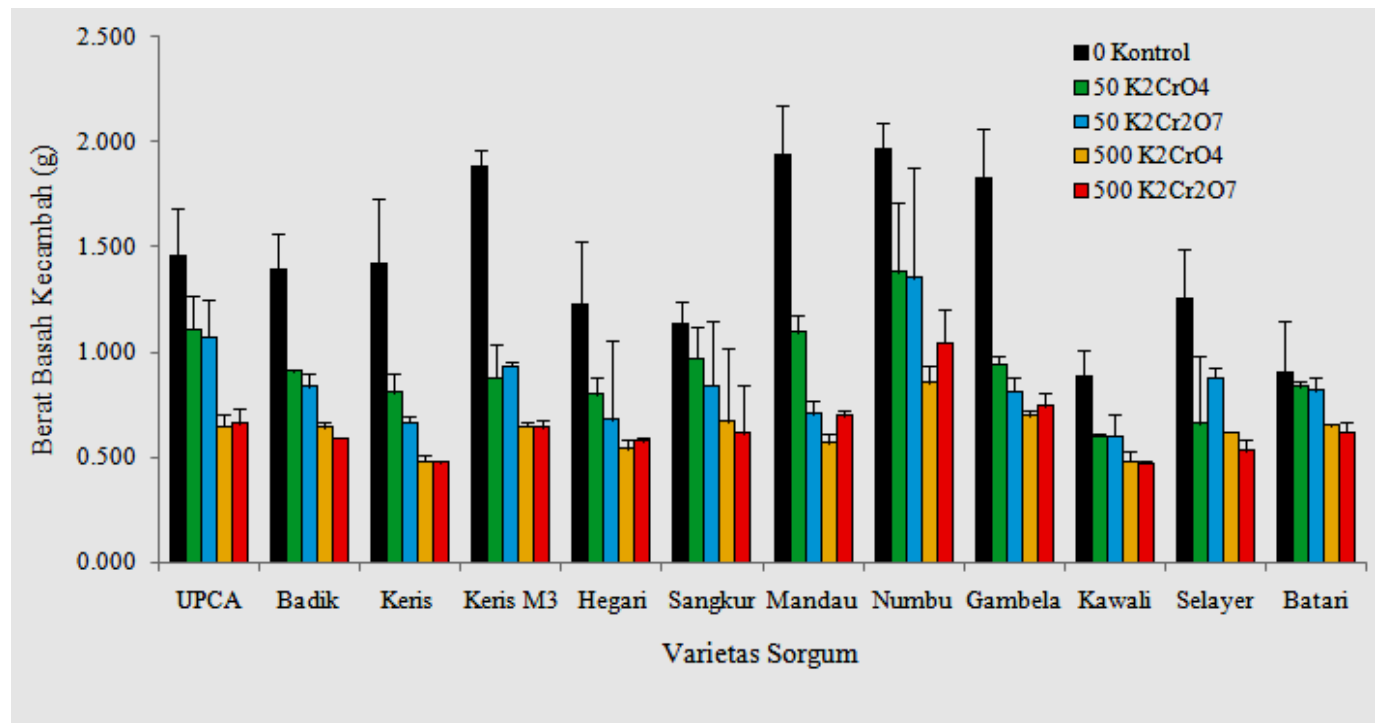

Gambar 4. Berat basah kecambah dari 12 varietas sorgum pada perlakuan bentuk dan konsentrasi $\mathrm{Cr}^{6+}\left(\mathrm{K}_{2} \mathrm{CrO}_{4}\right.$ dan $\mathrm{K}_{2} \mathrm{Cr}_{2} \mathrm{O}_{7}$ )

Di antara 12 varietas sorgum yang diuji, Batari menunjukkan penurunan biomassa basah dan kering kecambah paling kecil dibandingkan varietas lain, pada perlakuan $\mathrm{Cr}^{6+}$ dalam bentuk kromat maupun dikromat sebesar 50 dan $500 \mathrm{mg}$ $\mathrm{Cr} / \mathrm{l}$. Pada perlakuan $\mathrm{Cr}$ sebesar $50 \mathrm{mg} \mathrm{Cr} / \mathrm{l}$, penurunan berat basah paling besar dijumpai pada varietas Keris M3 sebesar 53,24\% (perlakuan kromat) dan Mandau sebesar $62,74 \%$ (perlakuan dikromat), sedangkan berat kering mengalami penurunan paling besar pada varietas Keris sebesar 46,54\% (perlakuan kromat) dan Mandau sebesar 62,74 (perlakuan dikromat).

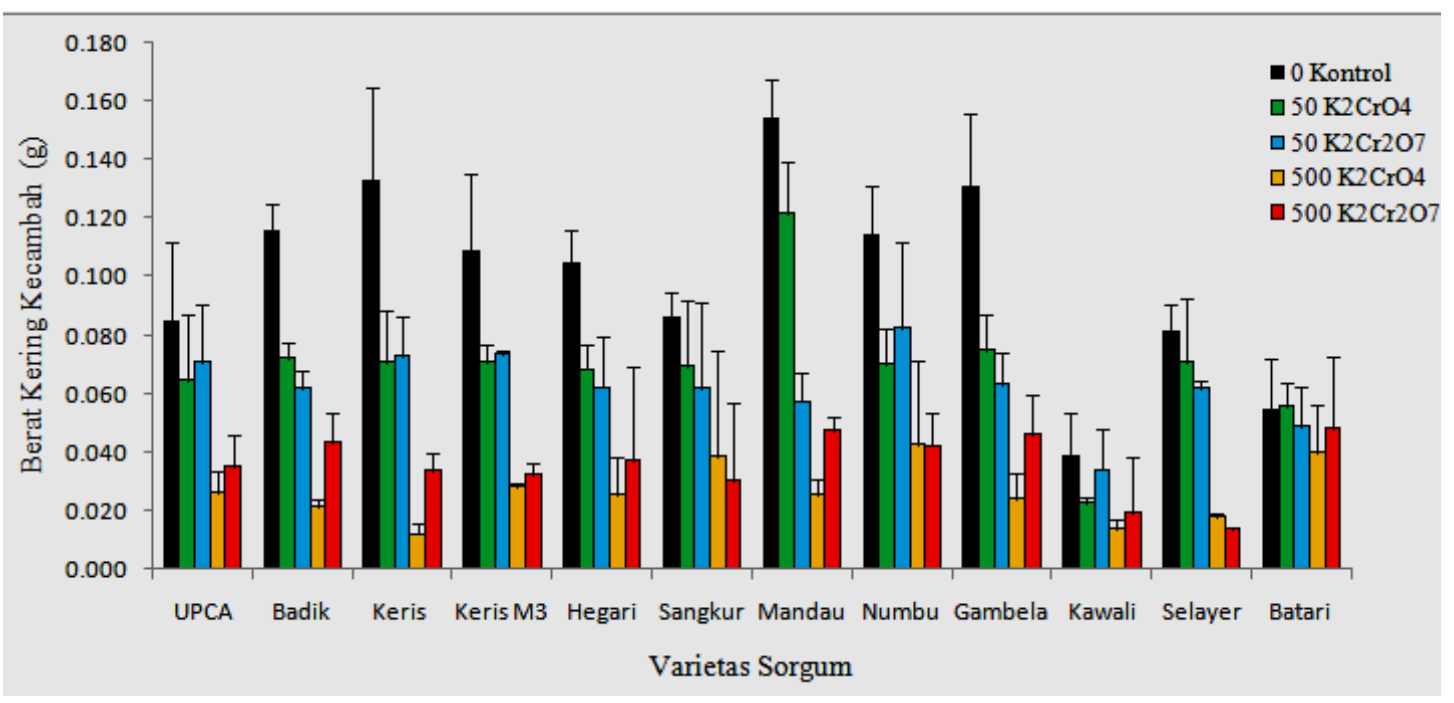

Gambar 5. Berat kering kecambah dari 12 varietas sorgum pada perlakuan bentuk dan konsentrasi $\mathrm{Cr}^{6+}\left(\mathrm{K}_{2} \mathrm{CrO}_{4}\right.$ dan $\mathrm{K}_{2} \mathrm{Cr}_{2} \mathrm{O}_{7}$ ) 
Pada perlakuan $\mathrm{Cr}$ sebesar $500 \mathrm{mg} \mathrm{Cr} / \mathrm{l}$, penurunan berat basah kecambah paling besar ditunjukkan pada varietas Mandau sebesar 70,72\% (pada perlakuan kromat) dan varietas Keris sebesar $66,32 \%$ (pada perlakuan dikromat). Penurunan berat kering kecambah pada perlakuan $\mathrm{Cr}$ sebesar $500 \mathrm{mg} \mathrm{Cr} / 1$ paling besar ditunjukkan pada Keris sebesar 90,96\% (pada perlakuan kromat) dan varietas Selayer sebesar 82,67\% (pada perlakuan dikromat). Menurut Sharma et al. (2003) penurunan biomassa kecambah baik berat basah maupun kering disebabkan oleh terjadinya perubahan metabolisme karbohidrat dan nitrogen, penurunan sintesis protein dan rendahnya reaksi fotosintetik. Penurunan biomassa basah dan kering kecambah akibat perlakuan $\mathrm{Cr}^{6+}$, juga dilaporkan pada Cucumis sativus oleh Verma et al. (2009), namun senyawanya berbeda yaitu dalam bentuk $\mathrm{CrO}_{3}$.

Nilai indeks vigor kecambah dari 12 varietas sorgum yang diuji mengalami penurunan pada perlakuan bentuk (kromat dan dikromat) dan konsentrasi $\mathrm{Cr}^{6+}(50$ dan $500 \mathrm{mg} \mathrm{Cr} / \mathrm{l})$. Perlakuan kromat dan dikromat menyebabkan rata-rata penurunan nilai SVI dengan nilai yang tidak berbeda nyata baik pada konsentrasi 50 maupun $500 \mathrm{mg} \mathrm{Cr} / \mathrm{l}$. Perlakuan $\mathrm{Cr}^{6+}$ (kromat dan dikromat) menurunkan nilai SVI dari 12 varietas dengan rata-rata mencapai $75,36 \%$ dengan kisaran antara 54,9 - 91,3\%, sedangkan pada konsentrasi $500 \mathrm{mg} \mathrm{Cr} / \mathrm{l}$ mencapai 94,5\% (berkisar antara 73,9 - 98,9\%). Varietas yang mengalami penurunan nilai SVI paling besar adalah pada perlakuan $\mathrm{Cr}^{6+}$ sebesar $50 \mathrm{mg} \mathrm{Cr} / \mathrm{l}$ adalah Hegari sebesar 91,25\% (perlakuan dikromat) dan Kawali sebesar 90,60\% (perlakuan kromat). Pada perlakuan $\mathrm{Cr}^{6+} 500 \mathrm{mg}$ $\mathrm{Cr} / \mathrm{l}$, varietas Hegari menunjukkan penurunan nilai SVI paling besar baik pada perlakuan dikromat maupun kromat, sedangkan varietas Sangkur mengalami penurunan paling kecil. Penurunan nilai indeks vigor kecambah akibat perlakuan $\mathrm{Cr}^{6+}$ sangat berkaitan dengan faktor yang mempengaruhi pertumbuhan memanjang kecambah dan besarnya persentase perkecambahan. Semakin rendah pertumbuhan memanjang kecambah dan semakin kecil persentase perkecambahan, maka nilai indeks vigor kecambah juga akan semakin kecil. Oleh karena itu, faktor yang menurunkan pertumbuhan panjang kecambah dan persentase perkecambahan akan juga menurunkan nilai indeks vigor kecambah.

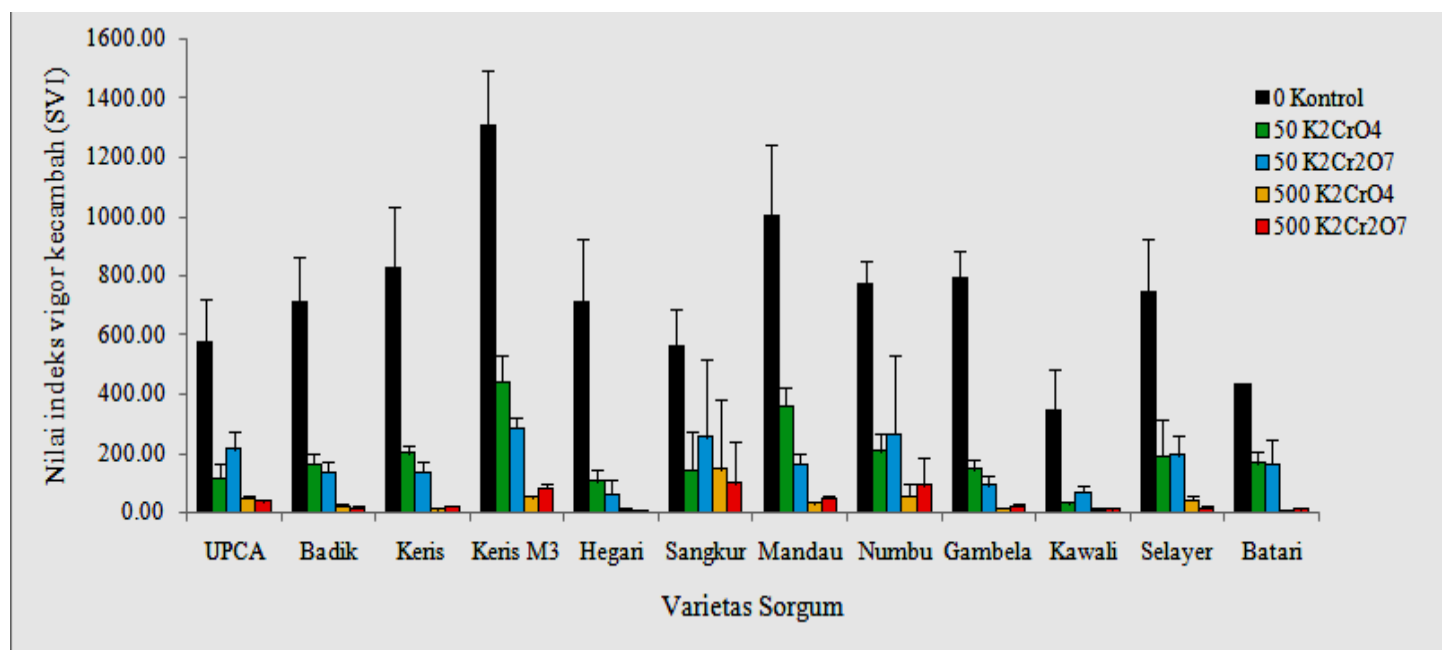

Gambar 6. Nilai indeks vigor kecambah (SVI) dari 12 varietas sorgum pada perlakuan bentuk dan konsentrasi $\mathrm{Cr}^{6+}\left(\mathrm{K}_{2} \mathrm{CrO}_{4}\right.$ dan $\left.\mathrm{K}_{2} \mathrm{Cr}_{2} \mathrm{O}_{7}\right)$ 
Berbeda dengan variabel yang lain, interaksi antara varietas dan perlakuan bentuk senyawa serta konsentrasi $\mathrm{Cr}^{6+}$ menunjukkan pengaruh tidak nyata terhadap persentase dan nilai indeks perkecambahan. Perlakuan bentuk senyawa (kromat dan dikromat) pada konsentrasi 50 dan $500 \mathrm{mg} \mathrm{Cr} / \mathrm{l}$ tidak selalu menurunkan persentase dan nilai indeks perkecambahan pada 12 varietas sorgum yang diuji. Pada perlakuan $\mathrm{Cr}^{6+}$ sebesar 50 $\mathrm{mg} \mathrm{Cr} / \mathrm{l}$ baik dalam bentuk kromat maupun dikromat cenderung meningkatkan persentase dan nilai indeks perkecambahan, yaitu rata-rata sebesar $2,77 \%$ (pada persentase perkecambahan) dan $0,93 \%$ (pada nilai indeks perkecambahan) pada 12 varietas yang diuji. Penurunan persentase dan nilai indeks perkecambahan pada 12 varietas sorgum dengan perlakuan $\mathrm{Cr}^{6+}$ sebesar $500 \mathrm{mg} \mathrm{Cr} / 1$ lebih rendah dibandingkan variabel yang lain, yaitu hanya mencapai rata-rata sebesar $4,84 \%$ (pada persentase perkecambahan) dan $27,03 \%$ (pada nilai indeks perkecambahan).

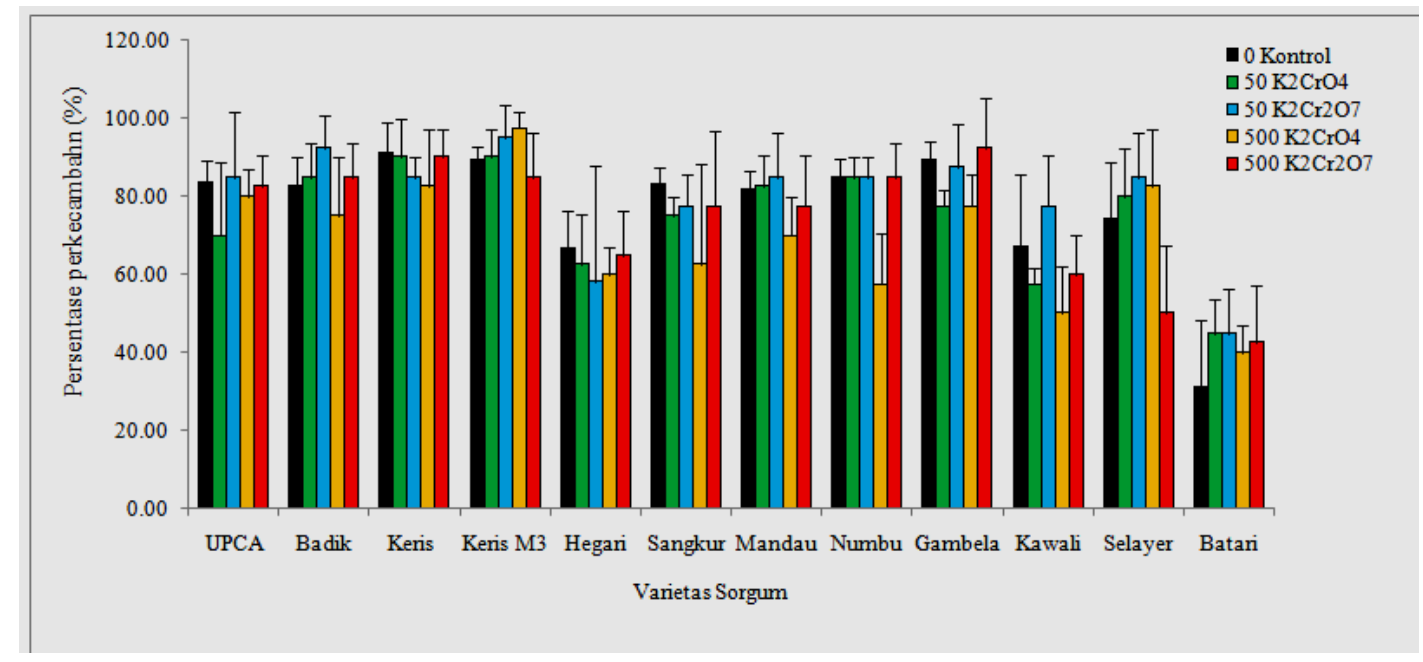

Gambar 7. Persentase perkecambahan dari 12 varietas sorgum pada perlakuan bentuk dan konsentrasi $\mathrm{Cr}^{6+}$ $\left(\mathrm{K}_{2} \mathrm{CrO}_{4}\right.$ dan $\left.\mathrm{K}_{2} \mathrm{Cr}_{2} \mathrm{O}_{7}\right)$

Di antara 12 varietas sorgum yang diuji, varietas Kawali menunjukkan peningkatan persentase perkecambahan baik pada perlakuan senyawa kromat dan dikromat dengan konsentrasi 50 dan $500 \mathrm{mg} \mathrm{Cr} / 1$. Sedangkan untuk nilai indeks perkecambahan, varietas Batari menunjukkan nilai paling besar hanya pada perlakuan kromat dan dikromat sebesar $50 \mathrm{mg} \mathrm{Cr} / \mathrm{l}$. Kawali mengalami penurunan persentase dan nilai indeks perkecambahan paling besar pada perlakuan kromat sebesar $50 \mathrm{mg} \mathrm{Cr} / \mathrm{l}$, sedangkan Selayer pada perlakuan dikromat sebesar $500 \mathrm{mg} \mathrm{Cr} / \mathrm{l}$. 


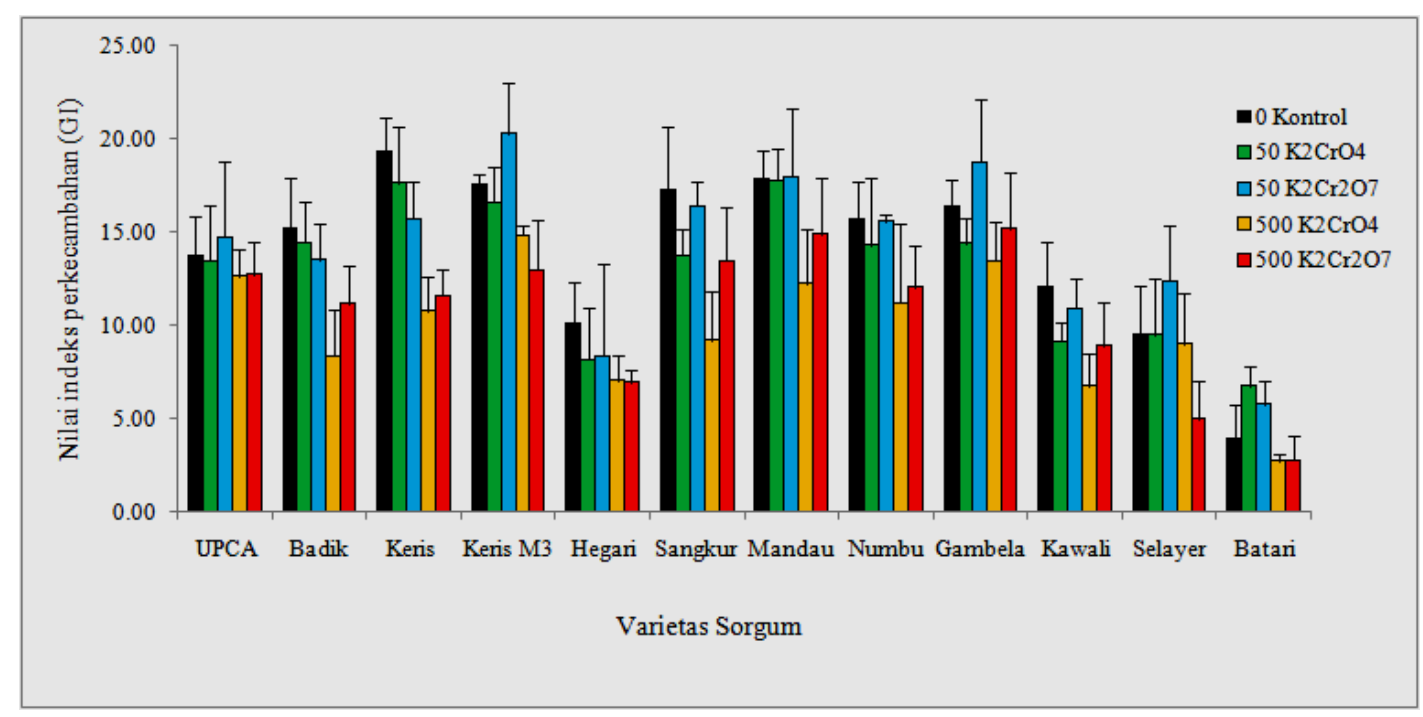

Gambar 8. Nilai indeks perkecambahan (GI) dari 12 varietas sorgum pada perlakuan bentuk dan konsentrasi $\mathrm{Cr}^{6+}$ $\left(\mathrm{K}_{2} \mathrm{CrO}_{4}\right.$ dan $\left.\mathrm{K}_{2} \mathrm{Cr}_{2} \mathrm{O}_{7}\right)$

Rendahnya penurunan persentase perkecambahan biji sorgum $(<50 \%)$ akibat perlakuan $\mathrm{Cr}^{6+}$, didukung oleh hasil penelitian yang telah ada. Persentase perkecambahan biji gulma Echinochloa colona hanya mengalami penurunan sebesar 25\% pada perlakuan $\mathrm{Cr} 200$ $\mu \mathrm{M}$ (Rout et al., 2000). Peralta et al. (2001) juga melaporkan bahwa biji Medicago sativa cv. Malone hanya mengalami penurunan sebesar 23\% pada perlakuan $\mathrm{Cr} 4 \mathrm{ppm}$. Bahkan perlakuan $\mathrm{Cr}^{6+}$ dalam bentuk senyawa dikromat $\left(\mathrm{K}_{2} \mathrm{Cr}_{2} \mathrm{O}_{7}\right)$, dilaporkan tidak mempengaruhi perkecambahan biji Salvia sclarea (Corradi et al., 1993) dan Pisum sativum (Bishnoi et al., 1993). Terjadinya penurunan persentase perkecambahan biji pada kondisi cekaman Cr dilaporkan oleh Zeid (2001), merupakan akibat adanya efek penghambatan $\mathrm{Cr}$ pada aktivitas enzim amilase, serta adanya hambatan transpor gula hasil hidrolisis cadangan makanan dalam endosperm ke bagian embrio.

\section{KESIMPULAN DAN SARAN}

Terdapat perbedaan respon perkecambahan dan pertumbuhan kecambah di antara 12 varietas sorgum terhadap cekaman $\mathrm{Cr}^{6+}$ dalam bentuk senyawa kromat $\left(\mathrm{K}_{2} \mathrm{CrO}_{4}\right)$ dan $\mathrm{K}_{2} \mathrm{Cr}_{2} \mathrm{O}_{7}$ sebesar 50 dan $500 \mathrm{mg} \mathrm{Cr} / \mathrm{l}$. Cekaman $\mathrm{Cr}^{6+}$ baik dalam bentuk kromat maupun dikromat menurunkan secara nyata panjang akar, panjang plumula, panjang kecambah, berat basah kecambah, berat kering kecambah, dan nilai SVI dari 12 varietas sorgum yang diuji. Penurunan pertumbuhan kecambah sorgum semakin meningkat sejalan dengan meningkatnya konsentrasi $\mathrm{Cr}^{6+}$. Senyawa $\mathrm{Cr}^{6+}$ dalam bentuk dikromat $\left(\mathrm{K}_{2} \mathrm{Cr}_{2} \mathrm{O}_{7}\right)$ menunjukkan efek lebih besar terhadap variabel perkecambahan dan pertumbuhan kecambah sorgum, apabila dibandingkan kromat $\left(\mathrm{K}_{2} \mathrm{CrO}_{4}\right)$. Persentase dan indeks perkecambahan 12 varietas sorgum mengalami peningkatan pada perlakuan $\mathrm{Cr}^{6+}$ dalam bentuk kromat dan dikromat sebesar $50 \mathrm{mg}$ $\mathrm{Cr} / \mathrm{l}$. Terdapat 6 varietas sorgum memiliki penurunan pertumbuhan kecambah tergolong tinggi dibanding yang lain, yaitu Kawali, Hegari, Keris, Keris M3, Mandau, dan Selayer, sedangkan 4 varietas yang lain menunjukkan penurunan lebih rendah (Sangkur, Selayer, Batari dan Numbu). Varietas Batari dan Selayer menunjukkan peningkatan persentase dan nilai indeks perkecambahan paling besar pada perlakuan kromat dan dikromat $50 \mathrm{mg} \mathrm{Cr} / \mathrm{l}$.

\section{DAFTAR PUSTAKA}

Aguilar, F.J.A., Wrobel, K., Lokits, K., Caruso, J.A., Alonso, A,C, Corona, J,F,G, and Wrobel, K. 2008. Analytical speciation of chromium in in-vitro culture of chromate- 
resistant filamentous fungi. Anal. Bioanal. Chem. 392:269-276

Ali, S., Zeng, F., and Zhang, G. 2011. The effect of chromium and aluminium on growth, root morphology, photosynthetic parameters and transpiration of the two barley cultivars. Biologia Plantarum 55(2):291-296

Bartlett, R.J. 1991. Chromium cycling in soil and water: links, gaps, and methods. Environmental Health Perspectives. 92:17 24

Bishnoi, N.R., Anita, D., Gupta, V.K., and Shawaney, S.K. 1993. Effect of chromium on seed germination, seedling growth and yield of peas. Agriculture Ecosystems and Environment. 47:47-57

Choppala, G., Bolan, N., Mallavarapu, M., and Chen, Z. 2010. Sorption and mobility of chromium species in a range of soil types, World Congress of Soil Science, Soil Solutions or a Changing World, Brisbane Australia

Carpici, E.B., Celik, N., and Bayram, G. 2009. Effects of salt stress on germination of some maize (Zea mays L.) cultivars. African Journal of Biotechnology. 8(19):4918-4922

Corradi, M.G., Bianchi, A., and Albasini, A. 1993. Chromium toxicity in Salvia sclarea. I. Effects of hexavalent chromium on seed germination and seedling development. Environmental Experimental Botany. 3(3):405-413

Dubey, S., Mishra, P., Dwivedi, S., Chatterjee, S., Bag, S.K., Mantri, S., Asif, M.H., Rai, A., Kumar, S., Shri, M., Tripathi, P., Tripathi, R.D., Tivedi, P.K., Cakrabarty, D., and Tuli, R. 2010. Transcriptomic and metabolomic shifts in rice roots in response to $\mathrm{Cr}(\mathrm{VI})$ stress. BMC Genomic. 11:648.

Ganesh, K.S., Baskaran, L., Rajasekaran, S., Sumathi, K., Chidambaram, A.L.A., and Sundaramoorthy, P. 2008. Chromium stress induced alterations in biochemical and enzyme metabolism in aquatic and terrestrial plants. Colloids and Surfaces B:Biointerfaces. 63(2):159-163
Gheju, M., Balcu, I., and Ciopec, M. 2009. Analysis of hexavalent chromium uptake by plants in polluted soils. Ovidius University Annals of Chemistry. 20(1):127-131

Gupta, S., Srivastava, S. and Saradhi, P.P. 2009. Chromium increases photosystem 2 activity in Brassica juncea. Biologia Plantarum. 53(1):100-104

Gyawali, R. dan Lekhak, H.D.2006. Chromium tolerance of rice (Oryza sativa) cultivar from Kathmandu Valley. Scientific World. 4(4): 102-106

Jahangir, M.M., Amjad, M., Afzal, I., Iqbal, Q., and Nawaz, A. 2009. Lettuce achene invigoration through osmopriming at supraoptimal temperature. Pak. J. Agric. Sci. 46(1):1-5

James, B.R. 2002. Chemical Transformations of chromium in soils: relevance to mobility, bio-availability and remediation, The Chromium File from the International Chromium Development Association.

Jamali, M.K., Kazi, T.G., Arain, M.B., Afridi, H.I., Jalbani, N., Baig, J.A., and Niaz, A. 2008. Effect of liming on the distribution of heavy metals in untreated industrial sewage sludge produced in Pakistan for the cultivation of Sorghum bicolor (L.). Environmentalist. 28:366-375

Kotas, J. and Stasicka, Z. 2000. Commentary: chromium occurrence in the environment and methods of its speciation. Environ. Poll. 107:263-283

Malmir, H.A. 2011. Comparison of antioxidant enzyme activities in leaves, stems and roots of Sorghum (Sorghum bicolor L.) exposed to chromium (VI). African Journal of Plant Science 5(8):436-444.

Mei, B,, Puryear, J,D,, and Newton, R,J, 2002, Assessment of $\mathrm{Cr}$ tolerance and accumulation in selected plant species, Plant and Soil. 247:223-231

Njoku dan Nweeze, 2009. Physiochemical Influence of soil minerals on the organic reduction of soil chromium, Lebanese Science Journal. 10(1):87-98 
Peralta, J.R., Gardea Torresdey, J.L., Tiemann, K.J., Gomes, E., Arteaga, S., and Parsons, J.G. 2001. Uptake and effects of five heavy metals on seed germination and plant growth in alfalfa (Medicago sativa L.). Bull. Environ. Contam. Toxicol. 66(6):727-734

Revathi, K., Haribabu, T.E., and Sudha, P.N. 2010. Phytoremediation of chromium contaminated soil using Sorghum plant, International Journal of Environmental Sciences. 2(2):417-428

Rout, G.R., Samantaray, S., and Das, P. 1997. Differential chromium tolerance among eight mung bean cultivars grown in nutrient culture. J. Plant.Nutr. 20: 341-347

Rout, G.R., Sanghamitra, S., and Das, P. 2000. Effects of chromium and nickel on germination and growth in tolerant and nontolerant populations of Echinochloa colona (L.). Chemosphere. 40:855-859

Samantaray, S., Rout G.R., and Das, P. 1998. Role of chromium on plant growth and metabolism. Acta Physiol. Plant 20(2):201212

Shanker, A.K., Cervantes, C., Loza-Tavera, H., and Avudainayagam, S. 2005. Chromium toxicity in plants. Environment International. 31:739-753.

Sharma, D.C., Sharma, C.P., and Tripathi, R.D. 2003. Phytotoxic lesions of chromium in maize. Chemosphere. 51(1):63-68

Sharma, I., Pati, P.K., dan Bhardwaj, R. 2011. Effect of 28-homobrassinolide on antioxidant defence system in Raphanus sativus L. under chromium toxicity. Ecotoxicology. 20:862-874

Sirappa, M.P. 2003. Prospek pengembangan sorghum di Indonesia sebagai komoditas alternatif untuk pangan, pakan dan industri, Jurnal Litbang Pertanian. 22(4):133-140

Subrahmanyam, D. 2008. Effects of chromium toxicity on leaf photosynthetic characteristics and oxidative changes in wheat (Triticum aestivum L.). Photosynthetica 46: 339-345

Talukdar, D. 2011. Effect of arsenic-induced toxicity on morphological traits of Trigonella foenum-graecum L. and Lathyrus sativus L. during germination and early seedling growth. Current Research Journal of Biological Sciences. 3(2):116-123

Vazquez, M.D., Poschenrieder, CH., and Barcello, J. 1987. Chromium VI induced structural and ultrastructural changes in bush bean plants (Phaseolus vulgaris L.). Annals of Botany. 59: 427-438

Verma, A., Kumar, R., dan Sharma, Y.K. 2009. Effect of chromium on seed germination, seedling growth and its remediation with zinc in cucumber (Cucumis sativus). Res. Environ. Life Sci. 2(3) 153-156

$\mathrm{Yu}$, X.Z. and Gu, J.D. 2007. Accumulation and distribution of trivalent chromium and effects on hybrid willow (Salix matsudana Koidz x S,alba L,) metabolism. Arch. Environ. Contam. Toxicol. 52:503-511

Yusro, 2001. Pengelompokan varietas/galur sorgum (Sorghum bicolor L. Moench) berdasarkan ciri-ciri morfologinya, Skripsi, Jurusan Statistika Fakultas Matematika dan Ilmu Pengetahuan, IPB, Bogor

Zayed, A.M. and Terry, N. 2003. Chromium in the environment: factor affecting biological remediation, Plant and Soil 249:139-156

Zeid, I.M. 2001. Responses of Phaseolus vulgaris to chromium and cobalt treatments. Biol. Plant. 44:111-115

Zou, J., Wang, M., Jiang, W., and Liu, D. 2006. Chromium accumulation and its effects on other mineral elements in Amaranthus viridis. Acta Biologica Cracoviensia Series Botanica. 48(1):7-12 